\title{
Bir Vergi Planlaması Aracı Olarak Devir Müessesesinin Değerlendirilmesi
}

Evaluation of the Transfer Facility as a Tax Planning Tool

\section{Fatih Saraçoğlu \& Muharrem Çakır}

Maliye Bölümü, Gazi Üniversitesi, Ankara, Türkiye

\begin{abstract}
Özet
Vergi planlaması; mükelleflerin imkanlarıyla ödemeleri gereken vergi arasındaki ilişkiyi belirlemeleri, yasalara aykırı olmayan girişim ve uygulamalarıyla ödemeleri gereken vergi tutarını asgariye indirme çabalarını ifade etmektedir. Vergiler, mükellef açısından bir maliyet unsuru olarak değerlendirilebilecek olup, mükellefler vergi ödemelerini ve dolayısıyla vergi yüklerini azaltmak; vergi sonrası gelirlerini artırarak yatırımlara ayırabilecekleri fonları artırmak, küresel rekabet ortamı içinde rekabet güçlerini yükseltmek, kayıt dışı ekonomi gibi nedenlerle vergi planlaması yapma yoluna gitmektedirler. Bu açıdan vergi kanunlarımızda yer alan muaflık, istisna ve indirimlere ilişkin düzenlemeler, uygun amortisman yönteminin seçilmesi, alacak ve borç senetlerinde reeskont uygulaması, yenileme fonu, şüpheli alacak karşılığı ayrılması gibi çeşitli yöntemlerden yararlanılabilmektedir. Bu çerçevede Kurumlar Vergisi Kanunu'nda (KVK) yer alan devir müessesesi de bir vergi planlaması aracı olarak kullanılabilecektir. KVK'nın 19/1. maddesine göre devir, tam mükellef kurumlar arasında kayıtlı değerler üzerinden ve bir bütün halinde devralma suretiyle gerçekleştirilen işlemlerdir. KVK'nın 9. maddesine göre de kurumların ticari faaliyetlerden doğan zararları belli şartların gerçekleşmesi durumunda, sonraki dönemlerde doğan kazançlardan indirilebilmektedir. Bu açıdan devir müessesesinin vergi planlaması yapmak isteyen işletmeler açısından kullanılabilecek araçlardan biri olduğu görülmektedir. Mükellefler devir müessesesinden yararlanarak daha az vergi ödeme imkanına kavuşacakları için bunu bir vergi planlaması aracı olarak kullanabileceklerdir.
\end{abstract}

\section{Abstract}

Tax planning refers to the efforts of the taxpayers to determine the relationship between the taxpayer's possibilities and the required taxes, and to minimize the amount of taxes required to be paid by means of non-contrary initiatives and practices. Taxes are regarded as a cost element in terms of taxpayers. So taxpayers are going to make tax planning by reason of decreasing tax payments and hence tax burdens, raising after-tax revenues, increasing their competitive power in the global competition environment, unregistered economy. In this respect, various methods can be used in our tax laws such as exemptions, exemptions and deductions for discounts, selecting the appropriate depreciation method, rediscounting receivables and debt securities, refunding funds, reserving doubtful receivables. In this context, the transfer institution which is included in the Corporate Tax Law (CTL) can also be used as a tax planning tool. According to article 19/1 of the CTL, the transfer is the transactions carried out by the acquirer over the registered values of the fullfledged taxpayer institutions and as a whole. According to article 9 of the CTL, the losses arising from the commercial activities of the institutions can be deducted from the gains arising in subsequent periods if certain conditions are met. From this point of view, it seems that the transfer facility is one of the tools that can be used in terms of businesses planning to make tax planning. Taxpayers will be able to use this as a tax planning tool because they will have the opportunity to pay less tax by making use of the transfer establishment.

Keywords: Tax planning, business, restructuring, transfer, loss deduction

CONTACT : Fatih Saraçoğlu, fatihsaracoglu@gazi.edu.tr, ORCID ID: orcid.org/0000-0002-5778-0488; Muharrem Çakır, mcakir@gazi.edu.tr, ORCID ID: orcid.org/0000-0003-0830-0430

Geliş Tarihi \& First Received : 02.08.2017

Kabul Tarihi \& Accepted : 02.10.2017 


\section{Giriş}

Mükellefler vergi ödemelerini ve dolayısıyla vergi yüklerini azaltmak, vergi sonrası gelirlerini artırarak yatırımlara ayırabilecekleri fonları artırmak, rekabet güçlerini yükseltmek ve kayıt dışı ekonomi gibi nedenlerle vergi planlaması yapma yoluna gitmektedirler.

İşletmeler, mali yapılarını güçlendirip sermayelerini artırarak ticari hayattaki yerlerini güçlendirebilmek amacıyla başka işletmelerle bütünleşme yoluna gidebilmekte; diğer işletmelerle entegrasyon yoluyla mali yapılarının güçlendirilmesi ve verimliliklerinin artırılması gibi amaçlarla devir müessesesinden yararlanabilmektedir. Öte yandan devir olunan işletme de ekonomik hayata kazandırılmış olmaktadır.

Bu kapsamda Kurumlar Vergisi Kanunu'nda (KVK) yer alan devir müessesesi çerçevesinde yer alan hükümler de vergi planlaması aracı olarak kullanılabilecektir.

Devir, birleşmenin özel bir şekli olup; bu durumda devralan kurumun tüzel kişiliği korunmakta, buna bir ya da birden fazla kurumun infisah (dağılma) yoluyla katılması söz konusu olmaktadır.

Mükellefler devir müessesesinden yararlanarak daha az vergi ödeme imkanına kavuşabilecekleri için bunu bir vergi planlaması aracı olarak kullanabileceklerdir.

Bir vergi planlaması aracı olarak devir müessesesinin değerlendirildiği bu çalışmada öncelikle vergi planlaması tanımlanarak, nedenleri ve araçları ortaya konulacak; daha sonra işletmelerin yeniden yapılanma nedenleri kısaca açıklandıktan sonra, işletmelerin yeniden yapılanması açısından devir işlemleri, vergi boyutu ve devir işleminde zarar mahsubu incelenecektir. Çalışmanın son bölümünde ise işletmelerin yeniden yapılanmasında devir işlemlerinin rolü, vergi planlaması açısından değerlendirilecektir.

\section{Vergi Planlamasının Tanımlanması, Nedenleri Ve Araçlan}

İşletmeler, en az tutarda vergi ödeyerek vergi tasarrufu ve avantajlar sağlamak, vergi yükünü en aza indirmek amacıyla vergi planlaması yapmaktadır.

Vergi planlamasına işletmeler çeşitli nedenlerle ihtiyaç duymakta olup, bu nedenler temel olarak işletmelerin karlılığının ve likiditesinin azalması, yüksek vergi oranları, rekabet koşulları, enflasyonist ortam, karışık ve sık sık değişen vergi mevzuatı ve vergi sisteminin adaletsizliği şeklinde sıralanabilir.

Ülkemizde Vergi Usul Kanunu, Gelir Vergisi Kanunu, Kurumlar Vergisi Kanunu, Özel Tüketim Vergisi Kanunu başta olmak üzere vergi kanunlarında vergi planlaması yapılmasına imkan sağlayan düzenlemelere yer verilmiştir.

\subsection{Vergi Planlamasının Tanımlanması}

Verginin ödenmesi her zaman sorunsuz gerçekleşmemekte; mükelleflerin bu ödemeye karşı kaçma, kaçınma, yansıtma gibi tepkiler göstermesi söz konusu olabilmektedir (Bilici, Bilici, 2013: 185). Bu tepki yasal düzenlemeler çerçevesinde olabileceği gibi yasalara aykırı biçimde de gerçekleşebilir. Mükelleflerin daha az vergi 
ödemek için elverişli yöntemleri kullanarak, mevzuatın tanıdığı haklar ve tercihlerden yararlanarak ödeyecekleri vergileri aşağı çekmesi yoluyla vergi avantajları sağlaması mümkündür.

Mükelleflerin vergi yüklerini azaltma amacıyla kanunların tanığı haklardan en uygunlarının belirlenmesine yönelik çalışmalar vergi planlaması kavramını ortaya çıkarmıştır (Yıldırım ve Demiraslan, 2006: 2). Vergi planlaması, bir takvim yılında maksimum vergi avantajı sağlayacak veya minimum vergi ödemeyi mümkün kılacak şekilde, vergisini zamanında ve eksiksiz olarak tahakkuk ettirip ödeyen mükellefler tarafından bilinçli ve ihtiyatlı olarak tasarlanan, geçmişten ve geleceğe yönelik olarak tahmin edilen genel işlemler, faaliyetler, düzenlemeler ve araştırma çabaları olarak belirtilmektedir (Amadasun ve İgbinosa, 2011: 53).

Mikro düzeyde ele alınarak kişisel ya da işletmeler açısından vergi planlamasından söz edilebileceği gibi, makro düzeyde ele alınarak devlet açısından da vergi planlamasından söz edilebilir.

Mikro vergi planlaması, mükelleflerin imkanlarıyla ödemeleri gereken vergi arasındaki ilişkiyi belirlemeleri, yasalara aykırı olmayan girişim ve uygulamalarıyla ödemeleri gereken vergi tutarını asgariye indirme çabaları iken; makro vergi planlaması devletin finansal ihtiyacının en uygun kaynaklardan, toplumun yaklaşımlarını, tavır ve davranışlarını dikkate alarak verginin konulma amaçlarına uygun olarak maksimum hizmeti sağlayacak şekilde vergi uygulamasının gerçekleştirilmesidir (Akdoğan, 2016: 194).

Vergi planlaması, mükellefler açısından ele alındığında, yasa boşluklarından yararlanmak, vergiye tabi işlemleri yapmamak, muaflık ve istisna kapsamına giren işlerle uğraşmak gibi uygulamalarla vergiyi doğuran olaya sebebiyet vermeden ya da en az tutarda vergi ödemesine yol açacak işlem ve uygulamalarla vergi yükünün aşağı çekilmesi biçiminde olabilir (Akdoğan, 2016: 194).

Mükelleflerin (işletmelerin) vergiye karşı tepkilerinin ve uyum sağlama süreçlerinin vergi mevzuatı çerçevesinde yönetilerek, vergi yükünün en aza indirilmesi amacıyla uygulanan bir vergi tasarrufu sağlama yöntemi (Oktar, 2004: 8) olan vergi planlaması; mükelleflerin, işletme üzerinde oluşacak vergi yükünü en aza indirmek amacıyla vergi kanunlarının kendilerine verdiği hakları en akılcı şekilde kullanarak vergi yüklerini azaltma çabaları (Şişman, 2003: 33) olarak ifade edilebilir.

Vergi planlaması, işletme yapıları ve örgütlenmesinin, iş yapma şekil ve süreçlerinin, mevzuatta yer alan indirim, istisna ve muafiyetlerin, çifte vergilemeyi önleme anlaşmalarının vergisel avantaj sağlayacak ve vergi yükünü en aza indirecek şekilde yasal düzenlemeler çerçevesinde gerçekleştirilen bir çalışmadır (İbiş, 2004: 73).

Tanımlardan hareketle; amaçları, araçları ve sonuçları da dikkate alınarak vergi planlaması bir başka biçimde şu şekilde tanımlanabilir. Vergi planlaması; işletme yapısı ve çalışma sürecini doğru biçimde yöneterek, yasal çerçeve içinde, vergiye karşı tepkilerinin azaltılması ve vergiye uyumlarının sağlanabilmesi amacıyla; vergiyi doğuran olaya sebebiyet vermeden ya da vergiye tabi işlemleri yapmadan, yasalarda 
tanınan haklardan ve boşluklardan, çifte vergilemeyi önleme anlaşmalarından yararlanarak, indirim, muafiyet ve istisnalar kapsamında faaliyetlerini sürdürerek, vergisel avantajlar sağlamak ve en az tutarda vergi ödemek yoluyla vergi yükünü en aza indirerek vergi tasarrufu sağlamaya çalışmaktır.

Tanımdan anlaşılacağı üzere, mükellefler açısından vergi planlamasının vergi yükünün en aza indirilmesi ve verginin en aza indirilmesi şeklinde iki yönü bulunmakta olup; vergi yükünün en aza indirilmesinde yasal boşluklardan yararlanılarak lehe uygulamalara dönüştürülmesi, verginin en aza indirilmesinde ise vergi dışı maliyetler dikkate alınmadan öncelikle efektif vergi oranlarının düşürülmesi hedeflenmektedir (Eroğlu, 2004: 5-6).

Vergi planlamasının verginin en aza indirilmesi biçimindeki ikinci yönü özellikle uluslararası vergi oranlarındaki farklılıkların lehe dönüştürülmesi yoluyla gerçekleştirilmekte olup (Eroğlu, 2004: 6); bu açıdan çok uluslu şirketler, ana şirketler ile değişik ülkelerdeki birden fazla bağlı şirketler aracılığıyla faaliyetlerini sürdürmekte oldukları için etkin bir vergi planlaması imkanına sahip olmaktadır ve karlarını yüksek vergi oranlı ülkelerden düşük vergi oranlı ülkelere kaydırarak veya kazançlarını düşük vergi oranlı ülkelerde oluşturarak vergi yüklerini azaltabilmektedir (Çakır, 2016: 152).

\subsection{Vergi Planlamasının Nedenleri}

Vergi planlamasına işletmeler çeşitli nedenlerle ihtiyaç duymakta olup, bunlar temel olarak; işletmelerin karlılı̆̆ının ve likiditesinin azalması, yüksek vergi oranları, rekabet koşulları, enflasyonist ortam, karışık ve sık sık değişen vergi mevzuatı ve vergi sisteminin adaletsizliği şeklinde sıralanabilir.

İşletmelerin Karlılığının ve Likiditesinin Azalması: Vergi, işletmeler açısından bir maliyet unsuru olarak değerlendirilebilecek olup, vergi ödemeleri nedeniyle karlılığı azalan işletmelerin likiditelerinin de azalması işletmeleri yasal çerçeve içinde daha az vergi ödeme yollarını araştırmalarına neden olmaktadır. İşletmelerin ellerinde kalacak fonun en az seviyede azalmasını ya da bu fonun artmasını sağlayacak girişimlerde bulunması vergi planlaması yapmalarını gerektirmektedir (Şişman, 2003: 34-35).

Vergi nedeniyle üretim maliyetlerinde karşılaşılabilecek artış ve yatırımların getirisi üzerinden alınacak vergilerin işletmelerin karlarını etkileyebilecek olması da işletmeleri vergi planlaması yapmaya itmektedir.

Yüksek Vergi Oranları: Ülkemizde vergi oranlarının boyutları da işletmeleri vergi planlaması yapmaya yönlendiren etkenlerin başında gelmektedir. Kurumlar vergisi oranının \%20 olarak uygulanması ve kar dağıtımına bağlı olarak vergi yükünün daha yüksek düzeylere ulaşabilmesi de işletmeleri vergi planlaması yaparak daha az vergi ödeyebilme imkanlarını araştırmaya yönlendirmektedir.

Rekabet Koşulları: Bir yanda vergi planlaması yoluyla yasalara uygun biçimde daha az vergi ödeyen işletmeler, diğer yanda kayıt dışı faaliyetlerde bulunan işletmeler ile vergisel yükümlülüklerini tam ve doğru biçimde yerine getiren ve vergi 
planlamasına gitmeyen işletmeler arasında rekabet açısından da olumsuzluk yaratmaktadır.

İki işletmeden biri yasal haklardan yararlanıp daha az vergi öderken; diğerinin bilinçsizlik nedeniyle daha fazla vergi ödemesi rekabet şansını azaltmakta; işletmeler rakipleriyle rekabet edebilmek amacıyla vergi planlamasına gitmektedir.

Yine faaliyetlerini kayıt dışı yürüten işletmeler de vergisel yükümlülüklerin dışında kaldıklarından haksız rekabete neden olmaktadır. Bu durum ise işletmeleri vergi planlaması yapmaya yönlendirmekte ve böylece rekabet güçlerini artırmaktadır.

Enflasyonist Ortam: İşletmelerin yaşamlarını rasyonel biçimde sürdürebilmeleri, gerek işletmeler gerekse ulusal ekonomi açısından doğru bilgilerin sağlanmasını gerektirmekte olup; enflasyonun süreklilik kazandığı bir ortamda fiyat hareketlerinin de dikkate alınması ve gerekli önlemlerin alınmasını gerektirmektedir (Saraçoğlu, 2005: 127).

Enflasyonist ortam işletmelerin yatırım kararlarını, finansman kaynaklarını, sermaye yapılarını, verimliliklerini ve ileriye yönelik projelerini etkilemekte olup; enflasyonist dönemlerde ortaya çıkan fiyat değişimlerinin işletme değerleri üzerindeki etkilerinin giderilebilmesi ve gerçek değerlere ulaşılarak işletmeyle ilgili olanların doğru yönlendirilebilmesi bakımından vergi planlaması bir ihtiyaç haline gelmektedir (Saraçoğlu, 2005: 192).

Karışık ve Sık Sık Değişen Vergi Mevzuatı: Vergide belirlilik ilkesi vergi uygulamalarının başarılı olabilmesi bakımından vergi ile ilgili kurum ve işlemlerin belli olmasını ve herkes tarafından anlaşılabilecek biçimde ortaya konulmasını gerektirirken; açıklık ilkesi, vergi uygulamasının amaçları, gerçekleştirilmeye çalışılan hedefler ve yapılması istenilen işlemlerin açıkça ortaya konulmasını gerektirmektedir (Akdoğan, 2016: 216-217).

Vergilemede istikrar ilkesi ise, vergilendirme tekniği konusunda yapılan düzenlemelerin sık sık değiştirilmemesini ve düzenli olmasını ifade etmektedir (Akdoğan, 2016: 220).

Ancak ülkemizde vergi kanunlarının anlaşılabilirliğinden ve işlemlerin açık biçimde ortaya konulduğundan söz edebilmek kolay değildir. Ayrıca ülkemizde sıklıkla vergi yasalarında değişikliklere gidilmesi de mükellefleri vergi planlaması yapmak zorunda birakmaktadır.

Vergi mevzuatının takip edilmesi ve faaliyetlerin mevzuata uygun biçimde sürdürülebilmesi; yasal yükümlülüklerin tam ve doğru biçimde yerine getirilebilmesi, teşvik ve kolaylıkların fark edilebilmesi ve vergisel avantajlardan yararlanılabilmesi vergi planlamasının gereklerinden biri olarak kaşımıza çıkmaktadır (İbiş, 2004: 75).

Vergi Sisteminin Adaletsizliği: İşletmeler, hukuki yapıları, sermaye yapıları, faaliyet alanları, faaliyet bölgeleri gibi çeşitli etkenlere bağlı olarak farklı vergisel uygulamalara tabi olabilmekte ya da farklı uygulamalardan yararlanabilme imkanları 
doğabilmektedir. Bu durum özellikle vergi ayrıcalıklarından yararlanmak isteyen işletmeleri vergi planlamasına yönlendirmektedir.

Yine ülkemizde vergi mevzuatımızda yer alan uzlaşma müessesesi ve sıklıkla gündeme gelen vergi afları da mükellefleri vergi planlaması yapmak zorunda birakmaktadir.

\subsection{Vergi Planlaması Araçları}

Ülkemizde vergilemeye ilişkin genel hükümlerin yer aldığı Vergi Usul Kanunu'nun (VUK) yanısıra, Türk vergi sistemini oluşturan vergi yasalarında da vergi planlaması yapmaya imkan sağlayan düzenlemeler yer almaktadır.

VUK'da yer alan başlıca düzenlemeler alacak ve borç senetlerine reeskont ayrılması, değersiz alacakların gider yazılması ve şüpheli alacaklar ve vazgeçilen alacaklar için karşılık ayrılması, amortisman ayrılması ve amortisman yöntemlerinde değişikliğe gidilmesi, yenileme fonu uygulaması, uzlaşma müessesesi vergi planlaması aracı olarak kullanılabilmektedir (Yusufoğlu, 2016: 149).

Vergi planlamasına yönelik olarak Gelir Vergisi Kanunu'nda (GVK) yer alan düzenlemeler genel olarak kazancın tespitinde indirilebilecek giderler, 89. madde çerçevesinde beyanname üzerinden yapılabilecek indirimler ve çeşitli istisna uygulamaları biçiminde karşımıza çıkmaktadır.

$\mathrm{Bu}$ açıdan GVK'nın 40. maddesinde düzenlenmiş olan ticari kazancın gerçek usulde tespitinde indirilebilecek giderlerin yanısıra diğer gelir unsurlarının tespitinde indirilebilecek giderler, 89. madde çerçevesinde hayat sigortası ve şahıs sigortası primlerinin indirimi, eğitim ve sağlık harcamalarının indirimi, korumalı işyeri indirimi gibi düzenlemeler ile gayrimenkul sermaye iratlarında istisna, genç girişimcilere yönelik kazanç istisnası, teknoloji geliştirme bölgelerinde elde edilen kazançlara yönelik istisna, serbest bölgelerde elde edilen kazançlara yönelik istisna gibi düzenlemelerden söz edilebilecektir.

Kurumlar Vergisi Kanunu'nda (KVK) ise yine kazancin tespitinde indirilecek giderler, kanunen kabul edilmeyen indirimler, muaflik ve istisnalar, transfer fiyatlandırmasına yönelik düzenlemeler vergi planlaması açısından ele alınabilecektir.

Öte yandan özellikle indirimli kurumlar vergisi uygulaması vergi planlaması açısından etkili bir araç olarak incelenebilecektir. Yine işletmelerin yeniden yapılanmalarına yönelik birleşme, devir, bölünme gibi işlemlerin vergisel boyutları vergi planlaması açısından araç olarak değerlendirilebilecektir.

Öte yandan özellikle Katma Değer Vergisi Kanunu (KDVK) ve Özel Tüketim Vergisi Kanunu (ÖTVK) gibi harcamalar üzerinden alınan vergilere ilişkin yasal düzenlemelerde yer alan istisnalar vergi planlaması aracı olarak ele alınabilecektir.

\section{2. İşletmelerde Yeniden Yapılanma İhtiyacı}

İşletmeler; rekabet güçlerini kaybetmeleri, ülke genelindeki ekonomik sorunlar, teşviklerin kalkması, ticaret reformu, iç ilişkilerde ve çevreyle 
ilişkilerde uyum sağlanması ve kurumsal bir organizasyon oluşturulması gibi nedenlerle yeniden yapılanma yoluna gidebilirler.

İşletmelerin yeniden yapılanmaları açısından büyüme ve gelişme olanakları, kuruluş aşamasındaki büyüklükleri ve amaçlarına bağlı olarak değişmektedir. İşletmeler kuruluş aşamasında genel olarak büyümeyi amaçlamakta; belirli büyüklüklerin üzerinde kurulmuş olmaları, ilerleyen zaman içerisinde bu işletmelerin büyüme olanaklarının ve hızlarının daha fazla olmasını sağlamaktadır. Çünkü belirli büyüklükteki işletmeler en azından rahatlıkla kredi bulabilmekte, bundan da önemlisi söz konusu işletmelerin rekabet gücü daha fazla olmaktadır (Saraçoğlu, 2005: 36).

Ölçek ekonomilerinden yararlanılabilmesi, yönetim kadrosunun gözden geçirilmesi, rekabet gücü sağlanması gibi nedenlerle işletmelerin diğer işletmelerle entegrasyonu, işletmelerin mali yapılarının güçlendirilmesi ve verimliliklerinin artırılmasında da etkili olabilecektir.

İşletmelerin birleşme yoluyla ulaşacakları ekonomik güç, sinerji etkisiyle tek tek güçleri toplamından daha yüksek olabilecek; tek tek sahip olunan yatırım, üretim ve pazarlama güçlerinden daha büyük güce sahip olacaklarından verimlilikleri artabilecektir. Tek şahıs işletmeleri ve şahıs ortaklıklarında olduğu gibi; sermaye şirketlerinin diğer işletmelerle entegrasyonu yoluyla mali yapılarının güçlendirilmesi, verimliliklerini artırılması ya da varlıklarının sona erdirilmesi açısından; KVK'da tasfiye1, birleşme2 ve devir işlemleriyle ilgili düzenlemelere yer verilmiştir.

\section{3. İşletmelerin Yeniden Yapılanması Açısından Devir İşlemleri, Vergi Boyutu Ve Vergi Planlaması}

\subsection{Devir İşlemleri}

Devralma yoluyla birleşme açısından;

$>$ gelir artışlarının sağlanması,

$>$ devralan şirketin hisse senetlerinin piyasa değerinin yükselmesi,

$>$ devralan şirketin likidite durumunun güçlenebilecek olması,

$>$ yabancı kaynak elde etme şansının artması,

$>$ makine ve donanım açısından tamamlayıcılık,

$>$ teknik bilgi akışının kolaylaşması,

$>$ araştırma - geliştirme olanaklarının artabilecek olması,

$>$ çeşitli risklerin ortadan kaldırılabilecek olması,

\footnotetext{
1 Tasfiye bir işletmenin mevcutlarının ve borçlarının belirlenmesi; alacaklarının tahsil edilmesi, mevcutlarının nakde çevrilmesi ve borçlarının ödenmesi sonucunda kalan nakdin ortaklara hisseleri oranında dağıtılmasıdır. KVK'nın 17. maddesinde tasfiye ile ilgili düzenlemelere yer verilmiş olup; tasfiye karı üzerinden kurumlar vergisi ödenmesi gerektiği belirtilmiştir.

2 Birleşme, birden fazla işletmenin kendi hukuki varlıklarını sona erdirerek yeni bir hukuki varlık oluşturmalarıdır. KVK'nın 18. maddesi gereğince birleşme nedeniyle infisah eden kurumlar açısından tasfiye işlemi yapılmakta; tasfiye karı yerine, birleşme karı vergi matrahı olarak dikkate alınmaktadır.
} 
etkili olmaktadır.

Devir, birleşmenin özel bir şekli olup; bu durumda devralan kurumun tüzel kişiliği korunmakta, buna bir ya da birden fazla kurumun infisah (dağılma) yoluyla katılması söz konusu olmaktadır. Birleşme ve devir iç içe olmakla birlikte, vergileme açısından iki işlem arasında farklılıklar bulunmaktadır. KVK'nın 20. maddesine göre, devirlerde belirli şartlara uyulması durumunda infisah eden kurumun sadece devir tarihine kadar sağladığı kazançlar vergilendirilip; doğrudan doğruya birleşmeden doğan karlar hesaplanmamakta ve vergilendirilmemektedir. Dolayısıyla devir işleminin vergisiz birleşme olarak nitelendirilmesi mümkündür.

Birden fazla işletmenin hukuki varlıklarını sona erdirerek yeni bir hukuki varlık oluşturmaları ya da devralan kurumun tüzel kişiliği korunurken buna diğer kurum ya da kurumların katılması; daha önce birbirinden bağımsız olarak faaliyette bulunan iki ya da daha fazla işletmenin bağımsızlıklarını kaybetmeleriyle bir araya gelmeleri sonucunu yaratmaktadır. Böylece mevcut işletme sayısı azalırken; birbirini bütünleyen kurumlar oluşmakta, bütünleşen işletmelerin mali yapıları güçlenmekte ve örgüt yapısı yenilenmektedir (Saraçoğlu, 2005: 141).

Bir işletmenin kısmen ya da tamamen devrinden elde edilebilen kazançların vergilendirme rejimi girişimcileri yönlendirmekte, birleşme sonucunda devir alınan işletmelere ait olabilecek zararların mahsup edilebilme olanakları da girişimciler üzerinde etkili olmaktadır (Gültekin, 1979: 196). Ayrıca kurumlar vergisinde tanınan imkanların yanısıra, katma değer vergisi açısından da devir nedeniyle vergi hesaplanmamakta; öte yandan devir işlemleri damga vergisi ve harçlardan istisna tutulmaktadır.

Yukarıda açıklanan nedenlerle sermaye şirketlerinin ölçek ekonomilerinden ya da büyük ölçekte faaliyette bulunmanın avantajlarından yararlanmak, mali yapılarını güçlendirerek daha etkin ve verimli çalışabilmek amacıyla birleşme yoluna gitmelerinin vergi kanunlarıyla engellenmemesi, teşvik edilmesi gerekmektedir.

\subsection{Devir İşlemi Ve Vergilendirme}

\subsubsection{Devir İşlemi}

Devir, birleşmenin özel bir şekli olup devralan kurumun tüzel kişiliği korunmakta, buna bir ya da birden fazla kurumun infisah yoluyla katılması söz konusu olmaktadır. KVK'da tam mükellef kurumlar arasında kayıtlı değerler üzerinden ve kül halinde devralma suretiyle gerçekleştirilen işlemler devir olarak nitelendirilmiştir (Şenyüz, 2007b: 396) ve şirketlerin teşviki amacıyla devir müessesesine yer verilmiştir (Bilici, 2016: 119). Bu yolla işletmelerin daha etkin ve verimli sağlayabilecek işlemleri vergilendirme açısından da kolaylaştırılmaktadır (Özmen, 2007: 605).

KVK'nın 19. maddesine göre, birleşme sonucunda infisah ${ }^{3}$ eden kurum ile birleşilen kurumun kanuni veya iş merkezlerinin Türkiye'de bulunması ve münfesih ${ }^{4}$

\footnotetext{
${ }^{3}$ İnfisah, bir tüzel kişiliğin öngörülen belli sebep veya durumların gerçekleşmesi halinde sona ermesidir.
} 
kurumun devir tarihindeki bilanço değerlerinin, birleşilen kurum tarafından bir bütün halinde devralınması ve aynen bilançosuna geçirilmesi şartları dahilinde gerçekleşen birleşmeler devir hükmündedir (Akdoğan, 2014: 453). Ayrıca kurumların belirtilen şartlar dahilinde tür değiştirmeleri de devir hükmünde sayılmaktadır.

\subsubsection{Devir İşleminde Vergilendirme}

KVK'nın 20. maddesine göre de devirlerde, aşağıdaki şartlara uyulduğu takdirde, münfesih kurumun sadece devir tarihine kadar elde ettiği kazançlar vergilendirilmekte; birleşmeden doğan karlar hesaplanmamakta ve vergilendirilmemektedir.

* Münfesih kurum ile birleşilen kurum;

devir tarihi itibariyle hazırlayacakları ve müştereken imzalayacakları münfesih kuruma ait kurumlar vergisi beyannamesi ile,

$>$ devir işleminin hesap döneminin kapandığı aydan kurumlar vergisi beyannamesinin verildiği ayın sonuna kadar geçen süre içerisinde yapılması halinde, münfesih kurumun önceki hesap dönemine ilişkin olarak hazırlayacakları ve müştereken imzalayacakları münfesih kuruma ait kurumlar vergisi beyannamesini,

birleşmenin Ticaret Sicili Gazetesinde ilan edildiği tarihten itibaren 30 gün içinde münfesih kurumun bağlı bulunduğu vergi dairesine vereceklerdir.

Birleşilen kurum, münfesih kurumun tahakkuk etmiş ve edecek vergi borçlarını ödeyeceğini ve diğer ödevlerini yerine getireceğini münfesih kurumun birleşme sebebiyle verilecek olan kurumlar vergisi beyannamesinin ekinde vereceği bir taahhütname ile taahhüt edecektir. Mahallin en büyük mal memuru, bu hususta birleşilen kurumdan ayrıca teminat isteyebilecektir (Öner, 2015: 215).

Doğrudan doğruya devirden doğan kazançlar vergilendirmeye tabi tutulmadığı için devir kavramı yerine vergisiz birleşme kavramı da kullanılmaktadır (Şenyüz, 2007a: 132).

Şirket yetkili kurulunun devre ilişkin kararının ticaret sicilinde tescil edildiği tarih, devir tarihi sayılmaktadır.

Devir halinde aslında vergiden vazgeçilmemekte, sadece bu karın hesaplanması ötelenmektedir (Türk ve Buyruk, 2016: 94). Çünkü bilanço değerlerinin birleşilen kurum tarafından bir bütün halinde devralınması ve aynen bilançosuna geçirilmesi gerekmekte olup; yapılması gereken işlem birleşecek iki şirketin bilanço değerlerinin birbiriyle toplanmasından ibarettir. Dolayısıyla birleşmeden sonra herhangi bir iktisadi kıymet, yeni kurum tarafından elden çıkartılırsa cari değeriyle defter değeri arasındaki fark kar olarak vergilendirilecektir (Türk ve Buyruk, 2016: 94).

${ }^{4}$ Münfesih; dağılmış, feshedilmiş anlamına gelmektedir. 
Devir konusunda kanunda öngörülen şartlar incelendiğinde, devralan kurumun bünyesinde oluşturulmayan birleşme karı tutarında bir meblağın, ileride devralan kurum nezdinde kar olarak ortaya çlkmasının garanti altına alındığı görülmektedir (İnelli, 2016: 86). Bu çerçevede vergi planlaması yapılarak bir başka şirket devralınabilecek ve bu yolla vergi ertelenebilecektir. Öte yandan birleşecek kurumlar arasında daha önceden borç alacak ilişkisinin olması durumunda da vergi planlaması yapan bir işletme açısından imkanlar sağlanmiştır.

Bir kurumun kendisinde iştiraki bulunan veya iştirak ettiği başka bir kurumu kül halinde devralması nedeniyle kurum bünyesinde yapacağ sermaye artışını söz konusu iştirak paylarına isabet eden tutarda daha az gerçekleşmesi KVK'nın 19/1. maddesinde belirtilen şartların ihlali anlamına gelmemektedir.

İştirakler hesabında yer alan değerin, iştirak hisselerinin itibari değerine eşit olmaması halinde aradaki müspet veya menfi farkın kurumun vergiye tabi kazancının tespiti ile ilgilendirilmeksizin geçici hesaplarda izlenmesi mümkün olup, bu geçici hesapların vergiye tabi kurum kazancının tespiti ile ilişkilendirilmeksizin kurum kayıtlarında sona erdirilmesi de mümkün bulunmaktadır.

Devir işleminde, işletmelerin finansal yapılarının güçlendirilmesi amacıyla, oluşacak karların işletmeden çekilmemesi koşuluyla devlet vergi alacağından vazgeçmekte olup; amaç, işletme kısmen ya da tamamen başka çatı altında yaşamaya devam edecekse, yeni işletmeyi iktisadi kıymetlerin defter değerinden güncel değerine getirilmesinden doğacak muhasebe karlarının vergisiyle finansman yüküne sokmamaktır (Türk ve Buyruk, 2015: 94).

\subsubsection{Devir İşleminde Zarar Mahsubu}

KVK'nın 9. maddesine göre, kurumlar vergisi matrahının tespitinde, kurumlar vergisi beyannamesinde her yıla ilişkin tutarlar ayrı ayrı gösterilmek ve 5 yıldan fazla nakledilmemek şartıyla devralınan kurumların devir tarihi itibariyle öz sermaye tutarını geçmeyen zararları indirim konusu yapılmaktadır.

Ancak, zararların indirilmesinde;

* son 5 yıla ilişkin kurumlar vergisi beyannamelerinin kanuni süresinde verilmiş olması ve

* devralınan kurumun faaliyetine devir veya bölünmenin meydana geldiği hesap döneminden itibaren en az 5 yıl süreyle devam edilmesi,

gerekmektedir.

Bu şartların ihlali halinde, zarar mahsupları nedeniyle zamanında tahakkuk ettirilmeyen vergiler için vergi ziyaı doğmuş sayılmaktadır (Vural, 2009: 459). 
Şirketlerin zararda olan başka bir şirketi devralarak kanunda öngörülen şartlar dahilinde bu zararları indirim konusu yapmaları mümkündür. Vergi planlaması yapan bir şirket bu yolla zararda olan bir başka şirketi devralarak vergi matrahını ve dolayısıyla vergisini azaltma imkanına kavuşabilecektir. Bu imkan KVK ile tanınmış bir imkandır. Ancak, 1 seri nolu kurumlar vergisi genel tebliğinde "Vergiden kaçınma amacına yönelik olarak ekonomiye kazandırlması mümkün olmayan kurumlarn devir veya bölünme suretiyle devralnmass ya da devralınan veya bölünen kurumlarm faaliyetinin 5 yıllık süre içinde arızi hale getirilerek kısmen durdurulması veya sona erdirilmesi gibi ekonomik olmayan sebeplerle devir ve bölünme işleminin yapılması halinde zarar mahsubu mümkün değildir." ifadesine yer verilmiş olup, buradaki "vergiden kaçınma amacına yönelik" ibaresi dikkat çekmektedir. Zira mükellefler vergi kaçıramaz, ancak vergiden kaçınabilirler. Tebliğdeki ibare ile mükelleflerin vergiden kaçınma hakları ellerinden alınmış olmaktadır (Kolotoğlu, 2014: 18) ve dolayısıyla mükelleflerin vergi planlaması yaparak kanuna uygun biçimde zararda olan şirketleri devralmasina engel olabilecektir.

Biri karlı diğeri zararlı iki şirketin karlı şirket üzerinde birleşmesinde birleşmede, zarar mahsubu açısından sınır ve şartlar bulunmakta iken; zararlı şirket üzerinde birleşmelerde, zararın mahsubu açısından, zamanaşımı süresi hariç, herhangi bir sınır ve şart bulunmamaktadır (Gökmen, 2014: 38). İşte vergi planlaması ya da mali danışmanlık hizmetleriyle devir ve devir durumunda zarar mahsubuna ilişkin açıklanan hususların dikkate alınarak vergi yükünün aşağıya çekilmesi mümkün olabilecektir.

\section{4. İşletmelerin Yeniden Yapılanmasında Devir İşlemlerinin Vergi Planlaması Açısından Değerlendirilmesi}

Girişimciler, başlangıçta ulaşmak istedikleri amaçlara ulaşmaları, ulaşamayacaklarını görmeleri ya da ellerindeki sermayelerini daha etkili ve verimli bir şekilde kullanabilmek amacıyla tasfiye, birleşme, devir, bölünme ve hisse değişimi gibi çeşitli işlemlere başvurabilmekte; söz konusu işlemlerin yapılması sırasında karşılaşabilecekleri vergi düzenlemeleri de girişimciler üzerinde etkili olmaktadır.

Vergi planlaması ve mali danışmanlık hizmetleri; işletme varlıklarının yönetimi, kaynaklarının kullanımı ve işletmenin piyasa değerinin maksimum kılınması, gerekli fon kaynaklarının belirlenmesi ve fonların sağlanması, finansal planlama ve denetimin gerçekleştirilmesi, kazanç dağıtımı, vergilemeden kaynaklanan sorunların analizi, vergi oranlarındaki ve vergi teşviklerindeki değişiklikler konusunda sağlayacağı katkılarla yönlendirici olabilecektir.

İşletmeler vergi planlaması yoluyla vergi ödemelerini en aza indirmeyi amaçlamakta; araştırma - planlama faaliyetlerinin vergi planlaması olanakları 
dikkate alınarak sürdürülmesi işletmelere daha az vergi ödeme olanağ1 sağlayabilmektedir.

İşletmelerin yeniden yapılanmasında bütünleşme ve bölünme işlemleri önemli fonksiyon görmekte; gerek tek şahıs işletmeleri ve şahıs şirketlerinin sermaye ortaklıklarına devri ya da dönüşümüne yönelik, gerekse sermaye ortaklıklarının kendi aralarındaki birleşme ve devir işlemlerine yönelik vergi kolaylıkları yeniden yapılanma olanakları sağlamaktadır.

Devir işleminde kanunda yer alan koşullar çerçevesinde vergi ödemelerinin ertelenmesi imkanının sağlanması ve zarar mahsubuna yönelik uygulamalar vergi planlaması aracı olarak kullanılarak bir yandan zararda olan işletmelerin ekonomiye kazandırılması, diğer yandan işletmelerin yeniden yapılanmanın avantajlarından yararlanması mümkün olabilecektir. Dolayısıyla vergi planlamasına imkan sağlayan düzenlemeler sırf vergi kaybına neden olduğu gerekçesiyle değerlendirilmemeli, vergilemenin ekonomik ve sosyal fonksiyonları da dikkate alınarak uygulamalar yön verilmelidir.

\section{Sonuç}

İşletmeler, büyümek, mali yapılarını güçlendirmek, finansal kaynak bulma olanaklarını artırmak ve finansman kolaylığı sağlamak, atıl kalan fonları kullanılabilmek, teknik donanımlarını artırmak, kurumlaşma, verimliliklerini artırmak, rekabeti kaldırmak, girdi akışını kolaylaştırmak (ucuz hammadde, yarı mamül ve hizmet sağlayabilmek), işbölümü ve uzmanlaşmanın avantajlarından yararlanmak, gelişmiş teknolojiden yararlanabilmek, kalifiye eleman temin edebilmek, genel yönetim giderlerini azaltabilmek, pazarlık gücünü artırmak gibi amaçlarla birleşme yoluna gittiklerinde, kendilerine vergi kolaylıkları sağlanması teşvik edici olabilecek ve uzun vadede vergi gelirlerinde artış sağlanabilecektir.

Dolayısıyla vergi uygulamalarının işletmelerin büyümeleri üzerindeki olumsuz etkilerinin azaltılması ve vergi mevzuatında işletmelerin büyümelerini teşvik edici düzenlemelere yer verilmesi gerekmektedir.

$\mathrm{Bu}$ tür düzenlemeler mali kaygilarla yönetildiğinde anlamı kalmayabilecek ve istenilen hedeflere ulaşılması da imkan dışı olacaktır. Dolayısıyla kanuni çerçevede vergi planlaması yaparak yeniden yapılanma yoluna giden işletmelerin ekonomik ve sosyal açıdan fonksiyonları da göz ardı edilmemeli, uzun vadede vergi hasılatında katkı sağlayabilecekleri de dikkate alınmalıdır.

\section{Kaynakça}

Akdoğan, A. (2016). Kamu Maliyesi, Ankara: Gazi Kitabevi.

Akdoğan, A. (2014). Vergi Hukuku ve Türk Vergi Sistemi, Ankara: Gazi Kitabevi.

Amadasun, A. B. Igbinosa, S. O. (2011). "Strategies For Effective Tax Planning".

Franklin Business \& Law Journal, Issue (2). 
Bilici, N. (2014). Türk Vergi Sistemi, C. 2, Ankara: Savaş Yayınevi.

Bilici, N., Bilici, A. (2013). Kamu Maliyesi, Ankara: Seçkin Yayıncılık.

Çakır, M. (2016, Ocak). “Agresif Vergi Planlaması Yöntemi Olarak Transfer Fiyatlandırması ve Türkiye Düzenlemelerinin Değerlendirilmesi”, Vergi Sorunları Dergisi, Say1 328.

Eroğlu, O. (2014). Kurumlar Vergisinde Vergi Planlaması, Bursa: Ekin Basım Yayın Dağıtım.

Gökmen, S. (2014, Ocak). “Zararlı Şirketlerin Devir Yoluyla Birleşmesinde Karşılaşılan Bir Çelişki", Vergi Sorunları Dergisi, Sayı 304.

Gültekin, M. (1979). “Vergilerin İşletmeler Üzerindeki Etkileri”, Vergi Sorunları Dergisi, 1979.

İbiş, C. (2004, Temmuz-Ağustos). "İşletmelerde Vergi Planlaması”, Mali Çözüm Dergisi, Say1 68.

İnelli, E. (2010, Kasım). "İştirak Ettiği Şirketi Devralan Kurumlarda Devir Sonrası Bilançoda Öz Sermayenin Tespitine İlişkin Özellikli Bir Durum", Vergi Dünyası Dergisi, Say1 351.

Kolotoğlu, O. (2014, Nisan). "Zararlı Veya Borca Batık Şirketlerin Bünyesinde Devir Yoluyla Birleşme", Vergi Sorunları Dergisi, Sayı 307.

Oktar, C. (2004). İşletmelerde Vergi Planlaması Ve Türkiye Örneği, İstanbul: Filiz Kitabevi.

Öner, E. (2015). Türk Vergi Sistemi, Ankara: Seçkin Yayıncılık.

Özmen, M. A., (2007). 5520 Sayılı Kurumlar Vergisi Kanunu Rehberi ve Revizyon, Ankara: Yaklaşım Yayıncılık.

Saraçoğlu, F. (2005). İşletmelerin Vergilendirilmesi Ve Kurumlaşma, Ankara: Turhan Kitabevi.

Şenyüz, D. (2007a). Açıklama Ve Yorumlu 5520 Sayılı Kurumlar Vergisi Kanunu, Ankara: Yaklaşım Yayıncılık.

Şenyüz, D. (2007b). Türk Vergi Sistemi, Ankara: Yaklaşım Yayınları.

Şişman, B. (2003). Işsletmelerde Vergi Planlaması Yöntemleri, Ankara: Yaklaşım Yayınları.

Türk, Y., Buyruk, A. Ö. (2016, Mayıs). “Tasfiye, Birleşme, Devir İle Bölünme İşlemleri Ve Vergisel Sonuçları - II", Vergi Dünyası Dergisi, Sayı 417.

Türk, Y., Buyruk, A. Ö. (2015, Kasım). “Tasfiye, Birleşme, Devir İle Bölünme İşlemleri Ve Vergisel Sonuçları - I", Vergi Dünyası Dergisi, Sayı 411.

Vural, İ. (2009). Yorum ve Açıklamalarla Kurumlar Vergisi Kanunu, Ankara: Gelirler Kontrolörleri Derneği Yayını.

Yıldırım, A., Demiraslan, İ. (2006, Ekim). “Vergi Planlaması Çalışmaları Çerçevesinde, Yatırım İndirimi İstisnasında 2006 Yilında Yapılan, 2007 Ve 2008 Yillarında Yapılacak Tercihin Belirlenmesi (Tercihte Başabaş Noktası Analizi)", Vergi Dünyası Dergisi, Sayı 302, Http://Vergidunyasi.Com.Tr/Dergiler.Php?İd=4467.

Yusufoğlu, A. (2016, Mart). “Türk Vergi Sisteminde Seçimlik Vergi Planlaması Araçları Ve Kısıtlayıcı Düzenlemeler", Vergi Sorunları Dergisi, Sayı 330. 